\title{
sciendo
}

\section{Relationship between VAT Revenue and Intermediate Consumption - A VAR Approach}

\author{
Victor OGNERU \\ Bucharest University of Economic Studies, Bucharest, Romania \\ Victorogneru@yahoo.co.uk \\ Oana Mădălina POPESCU \\ Bucharest University of Economic Studies, Bucharest, Romania \\ Predescu0ana85@yahoo.com \\ Stelian STANCU \\ Bucharest University of Economic Studies, Bucharest, Romania \\ StelianStancu@yahoo.com
}

\begin{abstract}
The paper analyzes the relationship between value added tax revenue and intermediate consumption in the case of Romania in the period January 2007 - September 2018 (quarterly data), using an unrestricted Vector Autoregression Model based on the rate of dynamic taxation's level (in terms of value added tax revenue) and the rate of dynamic intermediate consumption. In literature, is questioned only the relationship between tax revenue and gross domestic product. Our study emphasizes the link between tax revenue and parts of the own tax base. The relationship is questioned in both directions, namely with respect to the manner in which value added tax affect intermediate consumption and in terms of the influence of intermediate consumption on value added tax revenue in the case of Romania. Given that a significant part of the corporate taxpayers have left the value added tax regime, intermediate consumption is considered instead of final consumption. The analysis is focused on a specific relationship in order to assess the general impact of indirect taxation on production capacity of the undertakings. Our findings reveal that there is not a direct relationship between intermediate consumption and value added tax revenue at the level of Romania despite a such relationship at the EU28 level. Moreover, in the case of Romania a high volatility of intermediate consumption was found. Both the breakage between tax revenue and his tax base, and volatility of the tax base suggest an influence of hidden economy. For future concerns about tax policy development, a specific model for estimating and forecasting value added tax revenue should be developed for Romania. On the other hand, based on the findings of this study, a model can be developed to assess the impact of the hidden economy on the value added tax revenue.
\end{abstract}

Keywords: value added tax, VAR modeling, taxation, economic performance, fiscal policy

\section{Introduction}

Changes in fiscal policy aggregated with major economic fluctuations, especially post-crisis, call for a closer analysis of the relationship between tax bases and tax revenues. Usually, macroeconomic studies on the impact of taxation are limited to pursuing the relationship between revenue and gross domestic product (GDP), with or without the consideration of contextual variables. This article examines the nature of the relationship between intermediate consumption as part of the tax base for value added tax (VAT) and VAT revenue 
in order to identify the extent to which economic developments can affect tax revenue from indirect taxes. Somewhere else, we showed the atypical evolutions of tax bases and associated tax revenues in the case of Romania, including the evolution of the final consumption in relation to VAT. Why intermediate consumption? Although it accounts for only $0.1 \%$ of GDP, both in the EU-28 and, in particular, in Romania, from the point of view of VAT, intermediate consumption represents in Romania about $44 \%$ of the total tax base for this tax. Can be the intermediate consumption predictor for VAT revenue?

The assumed working hypothesis was that there is a direct (positive) relationship between intermediate consumption and VAT revenue. At the same time, however, given the fact that the value of transactions between companies is not available at any time, we have been interested in seeing how much the evolution of VAT revenue can be a predictor for the evolution of intermediate consumption. For this purpose, the growth rates and not the level values were considered as variables. For a better understanding of the nature of the link between the two variables we opted for Vector Autoregression Model (VAR). This kind of models include the influences of the previous values of the variables, and not only the impact of present values of variables considered. The multiple influence of the variables is also comprised.

The second section of this article surveys the relevant literature regarding the relationship between tax base and tax revenue as well as regarding determinants of tax revenue; the third section presents the methodology of analysis and describes data used; the fourth section describes the variables and presents the results; the last section is focused on conclusions.

\section{Literature review}

Literature is poor in analyzing the relationship between tax bases and tax revenues. Perhaps more extensive research on this type of relationship is that of Kawano and Slemrod (2012), which focuses on the link between changes in the tax base and changes in tax revenue in the field of corporate taxation, but this link is studied from the perspective of fiscal policy changes, in this case changes in tax rates. The analysis is, however, directed to reveal rather the strong link between tax rates and tax revenues than the link between tax bases and tax revenues. We believe that studying this type of link (i.e. relationship between tax bases and tax revenues) is much more important given that a tax rate, whatever that may be, is applied to a tax base which can be in compression or in expansion. In general, it is assumed that there is a direct link between the level of tax revenues and the tax rate, under conditions of perfect compliance by the taxpayers. In this way, a natural link between the tax base and the level of revenue is assumed, in this key being thought out the recommendation made by Vito Tanzi (2000) for the emerging countries to consolidate their tax revenues based on direct taxation by increasing the tax rates and thus reducing the reliance on foreign trade taxes.

In terms of VAT, the studies were initially focused on assessing the impact of this tax on international trade (Feldstein and Krugman, 1989) or on identifying the determinants of tax revenue (Bogetic and Hassan, 1993). Later, attention was directed to studying the effectiveness of this kind of tax (Bird and Gendron, 2006). More recently, the relationship between VAT revenue and total tax revenue has been studied, but in terms of the impact which tax system can have on economic growth (Okoli and Afolayan, 2015). The problem was formulated exclusively in terms of economic impact and less in terms of fiscal sustainability. The European Commission (2015) tends to be more interested in enhancing fiscal 
sustainability, with a positive effect on economic growth, fiscal policy stance being aimed at broadening tax bases rather than maximizing tax revenues (especially through quota increases).

Recent research focuses on analyzing the relationship between tax revenues and economic growth, either using a regression model in which the explanatory variables are the tax revenues of each type of tax, and GDP is the variable explained (Kalaš et al., 2018), or applying VAR models (Mutaşcu and Dănuleţiu, 2011) or by checking the Granger causality (Al-Abbadi and Abdel Khaliq, 2017). In the same line, Romer and Romer (2010) conducted their research focusing on the impact of fiscal policy changes on economic activity. The unrestricted VAR and structural VAR models were also applied to assess the macroeconomic effects of fiscal policy (Afonso and Sousa, 2011). In fact, this approach constitutes a return to the way of looking at taxation from an economic point of view. Economists' concerns were almost exclusively related to the influence of public spending on economic growth, rather than the influence of taxation, the main growth models being analyzed comprehensively by Barro, R. \& Sala-i-Martin, X.I. (1995). When tax revenues are taken into account, the meaning of the analysis is one from taxation to economic activity (Leibfritz et al., 1997; Perotti, 2004).

Mamatzakis (2005) analyzes for the case of Greece the interaction between output growth, tax mix and tax burden based on Impulse Response Function. De Castro Fernández \& Hernández de Cos (2006) estimate by means of the VAR methodology the influence of public spending and income for the case of Spain, finding that the increase of taxes only temporarily improves the public budget balance. Giordano et al. (2007) shows that, in the case of Italy, shocks to net income have negligible effects on all the variables. Kuismanen \& Kämppi (2010) use Vector Stochastic Process with dummy variables to estimate the influence that fiscal policy has on Finland's economic activity, finding that positive tax shock (or a policy that increases public sector revenue) seems to have a positive effect on investment and GDP.

For the case of Romania, the concerns were directed towards identifying the correlation patterns between the economic growth and the budgetary revenue, thus being assessed the relationship between the tax burden and the economic activity. Brașoveanu \& Brașoveanu (2008) find a negative link between economic growth and tax revenues for the period up to 2007. Enache (2009) notes that there is no strong link between fiscal policy and economic growth. Mureșan et al. (2014) analyze in particular the impact that VAT has on the economic activity, the authors developing a mathematical model meant to accurately provide the changes occurred in the economic activity induced by the reduction of taxation. Finally, Boiciuc (2015) analyzes, based on a VAR methodology, the effects of tax revenue shocks.

Causality has been studied, in general, in both ways, but only in relation to GDP, the purpose of the researches being to identify the link between economic growth and the tax system. In this article, we aim to identify predictors of either tax revenue, VAT in this case, or the tax base, the broader scope of research being the assessment of the sustainability of a tax system in a given economic context, and having regard to the fiscal policy in place.

\section{Methodology \\ Data description}

We have collected quarterly data for the period 2007 - 2018 (q3) for a selection of two fiscal and macroeconomic indicators for Romania and for the European Union, namely VAT revenue and Intermmediate Consumption. Data were colected from Eurostat. It was analyzed 
the relationship between the two on three stages: as volume, as growth rate and as share of GDP. The last stage was rejected because the indicators have the same value in time and both at the Romanian and EU-28 level. Analysis in volume was useful to understand the behavior of the selected variables. All data collected have been stored and processed in Excel.

\section{Method}

Based on the working hypothesis, we performed two unrestricted Vector Autoregression Model (VAR), one for Romania and one for EU-28 as a whole in order to compare the evolutions of the selected indicators in Romania with a benchmark.

The two variables are treated as endogenous variables, considering each equation in the VAR Model containing $\mathrm{k}$ lag values for the $\mathrm{t}$ period.

The general model ca be written as:

$$
\begin{gathered}
I C_{t}=c_{1}+\sum_{i=1}^{k} \beta_{1, i} I C_{t-i}+\sum_{i=1}^{k} \beta_{2, i} V^{k} A T R_{t-i}+\varepsilon_{1, t} \\
V A T R_{t}=c_{2}+\sum_{i=1}^{k} \beta_{3, i} V^{k} A T R_{t-i}+\sum_{i=1}^{k} \beta_{4, i} I C_{t-i}+\varepsilon_{2, t}
\end{gathered}
$$

where, $c j$ are constant, $\beta j$ represent the coefficients of the endogenous variables, IC is endogenous variable intermediate consumption growth rate, VATR is endogenous variable VAT revenue growth rate, and $\varepsilon j$ stand for terms of residual errors. Variables of the model are not log-transformed.

The sample period runs from 2007: q1 to 2018: q3. We have considered growth rates instead of nominal values to capture the dynamics of the two variables.

The steps followed in order to perform the econometric analysis were: (a) testing stationarity of variables, (b) testing Granger causality to identify possible causality relationships, (c) a joint lag selection and VAR specification, (d) stability test, (e) residuals tests, and (f) analyzing impulse response functions. Following Harvey's considerations (Harvey, 1990), we have used variables in level. In order to perform these steps of modelling, we used EViews 9.

(a) Stationarity has been verified with Augmented Dickey-Fuller test, firstly for the two variables in level (nominal values) and secondly for the two variables as growth rates. Variables were tested in level in order to identify the pattern of variation of the natural series given the fact that we did not use log-transformed variables. Testing variables in level with nominal values is only to inform about the nature of variation of the growth rates, differentiation of the first order being not necessary at this stage (we did not use in the VAR model the variables with the series of nominal values). We found out that the two variables are not stationary in level in the case of Romania, but are stationary in level in the case of EU-28. Variables considered as growth rates are also stationary for EU-28. In the case of Romania, variable VATR growth rates become stationary, and variable IC growth rates remain non-stationary.

(b) Granger causality was verified both for the two variables in level and as growth rates. Pairwise Granger Causality Tests were applied for 4 lags because we have quarterly data. We found out that there is a strong link between intermediate consumption and 
VAT revenue (considered in nominal values) at the level of EU-28, but seems to be not any link between the two in the case of Romania. The same situation is encountered in the case of growth rates.

(c) For the specification of VAR models we used variables as growth rates even if one of the variables is not stationary. The choice of the number of lags is made on the basis of the VAR Lag Order Selection Criteria, wich show that, by all criteria, the proper lag is 4 both for Romania and EU-28 as a whole.

(d) Stability of the model has been tested using VAR stability condition check test, finding out that both VAR models (for Romania and for EU-28) satisfy the stability condition.

(e) The residuals tests applied are VAR Residual Portmanteau Tests for Autocorrelations, VAR Residual Normality Tests, and VAR Residual Heteroskedasticity Tests.

(f) An impulse response function reveals the effect of a one-time shock to one of the innovations on current and future values of the endogenous variables.

\section{Results and discussions}

\section{Description of variables}

Variables VAT revenue and intermediate consumption are not stationary, in the case of Romania, and show a trend. Instead, at the EU-28 level, the two variables are stationary.
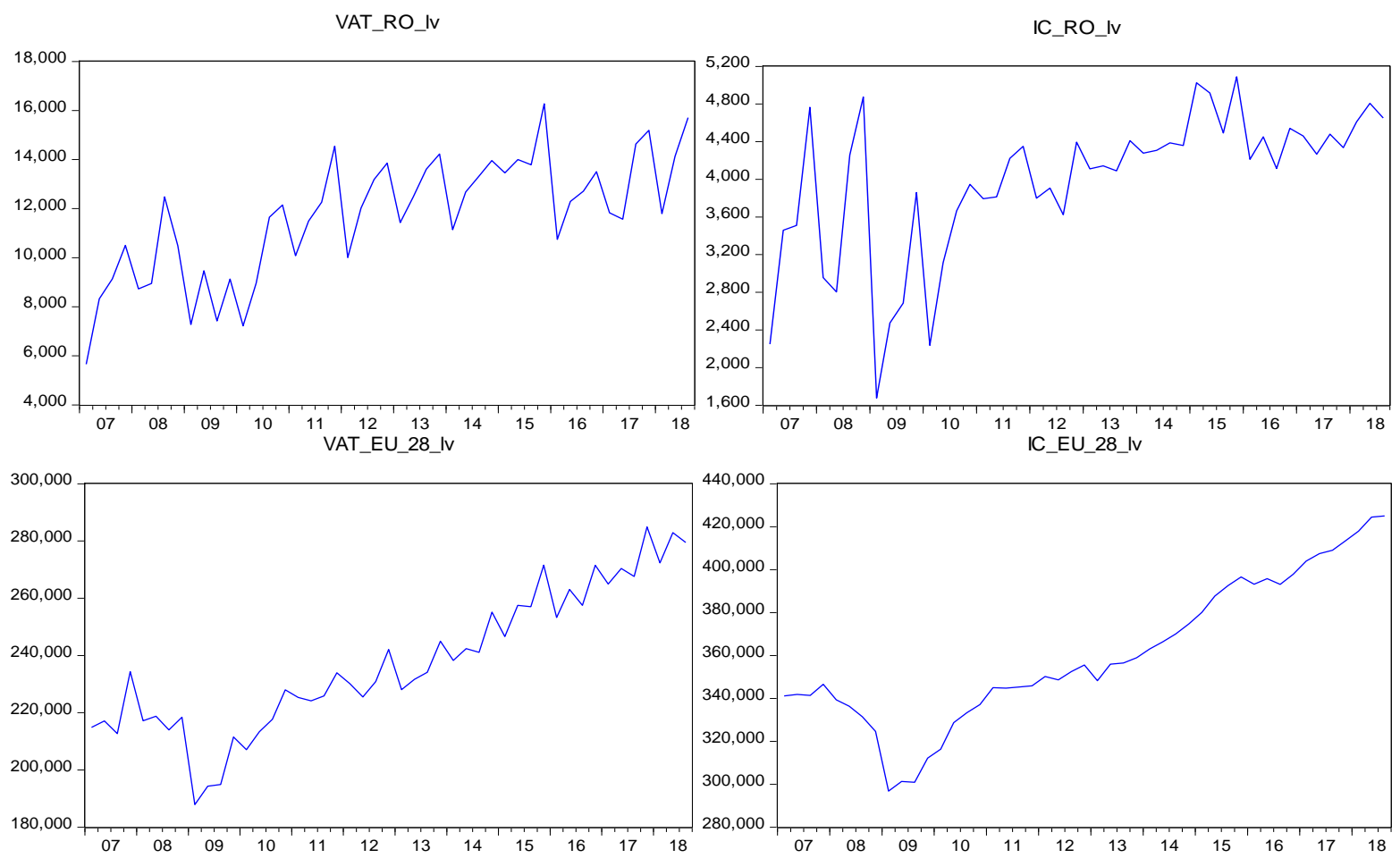

Figure 1 - The evolution of VAT revenue and intermediate consumption for Romania and EU28, in level

Source: Eurostat data and authors' own computations

The stationarity of the variables considered is obtained, in the case of Romania, by the first-order differentiation of the series (Table 1). 
Table 1 - The results of Augmented Dickey-Fuller (ADF) test for Romania for variables in level

\begin{tabular}{|l|l|l|l|}
\hline Variable & t-Statistic & Prob. & Lag Length \\
\hline VAT revenue in level & -1.071959 & 0.9210 & 7 \\
\hline VAT revenue first-order differentiation & -5.528187 & 0.0003 & 6 \\
\hline Intermediate consumption in level & -3.024826 & 0.1381 & 5 \\
\hline Intermediate consumption first-order differentiation & -10.50056 & 0.0000 & 2 \\
\hline \multicolumn{2}{|l|}{ Source: Authors' own research based on Eurostat data }
\end{tabular}

The two variables are stationary in level, in the case of EU-28, which makes it possible to analyze the link between them without further processing (Table 2). We recall that our analysis is focused on the relationship between growth rates and not on the relationship of the two variables considered in volume. However, viewing variables in volume is important because evolution patterns can be identified.

Table 2 - The results of Augmented Dickey-Fuller (ADF) test for EU-28 for variables in level

\begin{tabular}{|l|l|l|l|}
\hline Variable & t-Statistic & Prob. & Lag Length \\
\hline VAT revenue in level & -4.627714 & 0.0031 & 4 \\
\hline Intermediate consumption in level & -3.279175 & 0.0831 & 2 \\
\hline \multicolumn{2}{|l|}{ Source: Authors' own research based on Eurostat data }
\end{tabular}

Simple visualization of the evolution of the variables considered (Figure 1) reveals that the VAT revenue and the intermediate consumption in the economy tend to converge in the case of the EU-28, which is not verified in the case of Romania. Moreover, both variables have atypical developments in Romania if we relate to the aggregate evolution of the two variables at EU-28 level. A first conclusion that can be drawn from this is that both the macroeconomic environment and the VAT collection capacity are not stable (high volatility of the two variables is visible).

The atypical situation of Romania is also confirmed by the results of the Granger causality between the two variables (VAT revenue and intermediate consumption). Thus, for lag 4 (the option for 4 lags is given that the series are made up of quarterly data), in Romania there is no Granger causality in any direction; in other words neither of the two variables influences the other. In contrast, at EU-28 level, the link between the two variables is very tight (Table 3). It can be noticed that, at Union level, intermediate consumption causes Granger tax revenue from VAT, which corresponds to economic logic and confirms the main working hypothesis.

Table 3 - The results of Granger causality test for Romania and EU-28 for variables in level

\begin{tabular}{|l|l|l|l|}
\hline Pairwise Granger Causality Tests for 4 lags & Obs. & F-Statistic & Prob. \\
\hline IC_RO_LV does not Granger Cause VAT_RO_LV & 43 & 0.26196 & 0.9003 \\
\hline VAT_RO_LV does not Granger Cause IC_RO_LV & 43 & 0.96271 & 0.4405 \\
\hline IC_EU_28_LV does not Granger Cause VAT_EU_28_LV & 43 & 17.0038 & $1 . \mathrm{E}-07$ \\
\hline VAT_EU_28_LV does not Granger Cause IC_EU_28_LV & 43 & 2.14586 & 0.0964 \\
\hline
\end{tabular}

Source: Authors' own research based on Eurostat data Note - Abbreviations used for data processing are: IC_RO_lv for the level (volume) of intermediate consumption in Romania; VAT_RO_lv for the level (volume) of VAT revenue in Romania; IC_EU_28_lv for the level (volume) of intermediate consumption in EU-28; VAT_EU_28_lv for for the level (volume) of VAT revenue in EU-28 as a whole.

As regards the variable VAT revenue growth rates and the intermediate consumption growth rates, the link is maintained at Union level (EU-28), but the absence of the link 
remains in the case of Romania. The difference from the variables in volume is that in the case of Romania the variables considered tend to be stationary, except for intermediate consumption (Table 4).

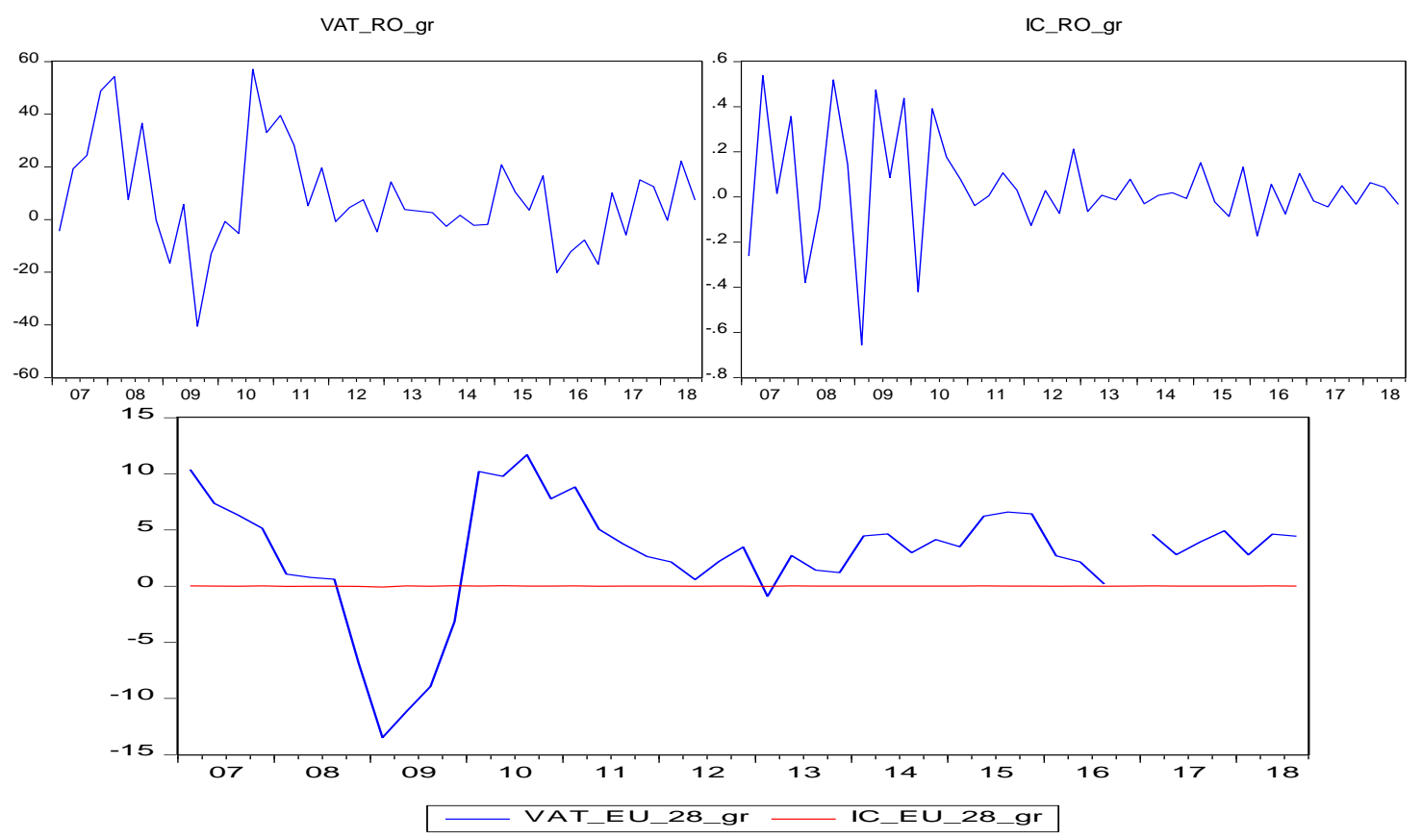

Figure 2 - The evolution of the growth rates of VAT revenue and growth rates of intermediate consumption in Romania and at the level of EU-28

Source: Eurostat data and authors' own computations

Note - Abbreviations used for processing data are: VAT_RO_gr for VAT revenue growth rates (current year on previous year) in Romania; IC_RO_gr for intermediate consumption growth rates in Romania; VAT_EU_28_gr for $V A T$ revenue growth rates in EU-28; IC_EU_28_gr for intermediate consumption growth rates in EU-28.

Table 4 - The results of Augmented Dickey-Fuller (ADF) test for growth rates in the case of Romania and EU-28

\begin{tabular}{|l|l|l|l|}
\hline Variable & t-Statistic & Prob. & Lag Length \\
\hline VAT revenue growth rates for Romania & -4.146030 & 0.0022 & 4 \\
\hline Intermediate consumption growth rates for Romania & -1.188678 & 0.6690 & 9 \\
\hline VAT revenue growth rates for EU-28 & -3.856466 & 0.0053 & 3 \\
\hline Intermediate consumption growth rates for EU-28 & -3.180101 & 0.0289 & 7 \\
\hline
\end{tabular}

Another conclusion that emerges from the results presented is that in Romania the economic environment seems to be extremely unstable, given the high level of volatility of the intermediate consumption (Figure 2), which can undermine the collection of VAT. However, the rate of increase in VAT revenue is a stationary variable, and it is suggested that achieving a certain level of collection is not related to economic fluctuations (!).

As with variables in volume, growth rates are correlated to EU-28, but are independent in the case of Romania (Table 5). 
Table 5 - The results of Granger causality test for Romania and EU-28 for growth rates

\begin{tabular}{|l|l|l|l|}
\hline Pairwise Granger Causality Tests for 4 lags & Obs. & F-Statistic & Prob. \\
\hline IC_RO_GR does not Granger Cause VAT_RO_GR & 43 & 1.67458 & 0.1786 \\
\hline VAT_RO_GR does not Granger Cause IC_RO_GR & 43 & 1.97394 & 0.1208 \\
\hline IC_EU_28_GR does not Granger Cause VAT_EU_28_GR & 38 & 11.3119 & 1. E-05 \\
\hline VAT_EU_28_GR does not Granger Cause IC_EU_28_GR & 38 & 4.49347 & 0.0060 \\
\hline
\end{tabular}

\section{Specification of VAR models}

The first step to take is to choose the appropriate number of lags. For both Romania and the Union as a whole, the number indicated by all criteria is 4 lags (Table 6 and 7).

Table 6 - The results of Lag Order Selection Criteria for Romania

\begin{tabular}{ccccccc}
\hline \hline Lag & LogL & LR & FPE & AIC & SC & HQ \\
\hline \hline 0 & -179.6913 & NA & 16.03897 & 8.450759 & 8.532675 & 8.480967 \\
1 & -170.1141 & 17.81803 & 12.37966 & 8.191355 & 8.437104 & 8.281979 \\
2 & -164.8138 & 9.368047 & 11.67247 & 8.130874 & 8.540455 & 8.281915 \\
3 & -150.8755 & 23.33857 & 7.379589 & 7.668627 & 8.242041 & 7.880084 \\
4 & -124.9645 & $40.97545^{*}$ & $2.681338^{*}$ & $6.649513^{*}$ & $7.386760^{*}$ & $6.921387^{*}$ \\
\hline \hline
\end{tabular}

* indicates lag order selected by the criterion

LR: sequential modified LR test statistic (each test at $5 \%$ level)

FPE: Final prediction error

AIC: Akaike information criterion

SC: Schwarz information criterion

HQ: Hannan-Quinn information criterion

Source: Authors' own research

Table 7 - The results of Lag Order Selection Criteria for EU-28

\begin{tabular}{ccccccc}
\hline \hline Lag & LogL & LR & FPE & AIC & SC & HQ \\
\hline \hline 0 & -14.49852 & NA & 0.008169 & 0.868343 & 0.954532 & 0.899009 \\
1 & 16.01159 & 56.20284 & 0.002025 & -0.526926 & -0.268359 & -0.434930 \\
2 & 24.61539 & 14.94345 & 0.001593 & -0.769231 & -0.338288 & -0.615905 \\
3 & 50.38746 & 42.04916 & 0.000509 & -1.915129 & -1.311808 & -1.700472 \\
4 & 59.97650 & $14.63591^{*}$ & $0.000383^{*}$ & $-2.209290^{*}$ & $-1.433591^{*}$ & $-1.933302^{*}$ \\
\hline \hline
\end{tabular}

Source: Authors' own research

Therefore, the VAR model is:

$$
\begin{gathered}
I C_{t}=c_{1}+\sum_{i=1}^{4} \beta_{1} I C_{t-i}+\sum_{i=1}^{4} \beta_{2} V A T R_{t-i}+\varepsilon_{1, t} \\
\operatorname{VATR}_{t}=c_{2}+\sum_{i=1}^{4} \beta_{3} V A T R_{t-i}+\sum_{i=1}^{4} \beta_{4} I C_{t-i}+\varepsilon_{2, t}
\end{gathered}
$$

or in simplified form: 


$$
\begin{gathered}
I C_{t}=c_{1}+\beta_{1} I C_{t-4}+\beta_{2} \text { VATR }_{t-4}+\varepsilon_{1, t} \\
\operatorname{VATR}_{t}=c_{2}+\beta_{3} \text { VATR }_{t-4}+\beta_{4} I C_{t-4}+\varepsilon_{2, t}
\end{gathered}
$$

The second step is to check the stability of the two models. The stability condition is met in both models (Tables 8 and 9).

Table 8 - The results for the stability condition - VAR model for Romania (4 lags)

\begin{tabular}{ll}
\hline \hline Root & Modulus \\
\hline \hline$-0.681565-0.637844 \mathrm{i}$ & 0.933475 \\
$-0.681565+0.637844 \mathrm{i}$ & 0.933475 \\
$0.781505-0.462827 \mathrm{i}$ & 0.908272 \\
$0.781505+0.462827 \mathrm{i}$ & 0.908272 \\
$-0.057989-0.899832 \mathrm{i}$ & 0.901699 \\
$-0.057989+0.899832 \mathrm{i}$ & 0.901699 \\
-0.859691 & 0.859691 \\
0.611566 & 0.611566 \\
\hline \hline
\end{tabular}

Source: Authors' own research

Table 9 - The results for the stability condition - VAR model for EU-28 (4 lags)

\begin{tabular}{ll}
\hline \hline Root & Modulus \\
\hline \hline$-0.253696-0.826887 \mathrm{i}$ & 0.864930 \\
$-0.253696+0.826887 \mathrm{i}$ & 0.864930 \\
$0.716380-0.369706 \mathrm{i}$ & 0.806154 \\
$0.716380+0.369706 \mathrm{i}$ & 0.806154 \\
$-0.751597-0.115562 \mathrm{i}$ & 0.760429 \\
$-0.751597+0.115562 \mathrm{i}$ & 0.760429 \\
$0.462757-0.408793 \mathrm{i}$ & 0.617459 \\
$0.462757+0.408793 \mathrm{i}$ & 0.617459 \\
\hline \hline
\end{tabular}

Source: Authors' own research

Estimation of VAR models is presented in Tables 10 and 11. It can be seen that regression equations have predictive power only for VAT receipts, considered as dependent variable. Therefore, even in the case of Romania, the sense of causality to be studied is from intermediate consumption to VAT revenue.

Table 10 - Vector Autoregression estimates for Romania

\begin{tabular}{ccc}
\hline \hline & & \\
& VAT_RO_GR & IC_RO_GR \\
\hline \hline & & \\
VAT_RO_GR(-1) & 0.205159 & -0.004131 \\
& $(0.12488)$ & $(0.00179)$ \\
& {$[1.64283]$} & {$[-2.30307]$}
\end{tabular}




\begin{tabular}{|c|c|c|}
\hline & VAT_RO_GR & IC_RO_GR \\
\hline VAT_RO_GR(-2) & $\begin{array}{c}0.461891 \\
(0.10578) \\
{[4.36643]}\end{array}$ & $\begin{array}{c}0.002202 \\
(0.00152) \\
{[1.44894]}\end{array}$ \\
\hline VAT_RO_GR(-3) & $\begin{array}{c}0.190922 \\
(0.10489) \\
{[1.82024]}\end{array}$ & $\begin{array}{c}0.000786 \\
(0.00151) \\
{[0.52186]}\end{array}$ \\
\hline VAT_RO_GR(-4) & $\begin{array}{r}-0.672335 \\
(0.09896) \\
{[-6.79372]}\end{array}$ & $\begin{array}{r}-0.002262 \\
(0.00142) \\
{[-1.59107]}\end{array}$ \\
\hline IC_RO_GR(-1) & $\begin{array}{c}13.62323 \\
(11.5648) \\
{[1.17799]}\end{array}$ & $\begin{array}{r}-0.369382 \\
(0.16612) \\
{[-2.22354]}\end{array}$ \\
\hline IC_RO_GR(-2) & $\begin{array}{l}2.445569 \\
(12.5586) \\
{[0.19473]}\end{array}$ & $\begin{array}{r}-0.290442 \\
(0.18040) \\
{[-1.60999]}\end{array}$ \\
\hline IC_RO_GR(-3) & $\begin{array}{c}14.24152 \\
(11.9075) \\
{[1.19601]}\end{array}$ & $\begin{array}{r}-0.123045 \\
(0.17105) \\
{[-0.71936]}\end{array}$ \\
\hline IC_RO_GR(-4) & $\begin{array}{r}-3.393980 \\
(11.3937) \\
{[-0.29788]}\end{array}$ & $\begin{array}{c}0.445629 \\
(0.16367) \\
{[2.72280]}\end{array}$ \\
\hline $\mathrm{C}$ & $\begin{array}{c}4.261535 \\
(2.18451) \\
{[1.95080]}\end{array}$ & $\begin{array}{r}0.061084 \\
(0.03138) \\
{[1.94661]}\end{array}$ \\
\hline R-squared & 0.741859 & 0.570785 \\
\hline Adj. R-squared & 0.681120 & 0.469793 \\
\hline Sum sq. resids & 3818.489 & 0.787915 \\
\hline S.E. equation & 10.59757 & 0.152230 \\
\hline F-statistic & 12.21388 & 5.651787 \\
\hline Log likelihood & -157.4722 & 24.97630 \\
\hline Akaike AIC & 7.742892 & -0.743084 \\
\hline Schwarz SC & 8.111515 & -0.374461 \\
\hline Mean dependent & 6.781354 & 0.024723 \\
\hline S.D. dependent & 18.76691 & 0.209063 \\
\hline
\end{tabular}

Standard errors in ( ) \& t-statistics in [ ]

Source: Authors' own research 
Table 11 - Vector Autoregression estimates for EU-28

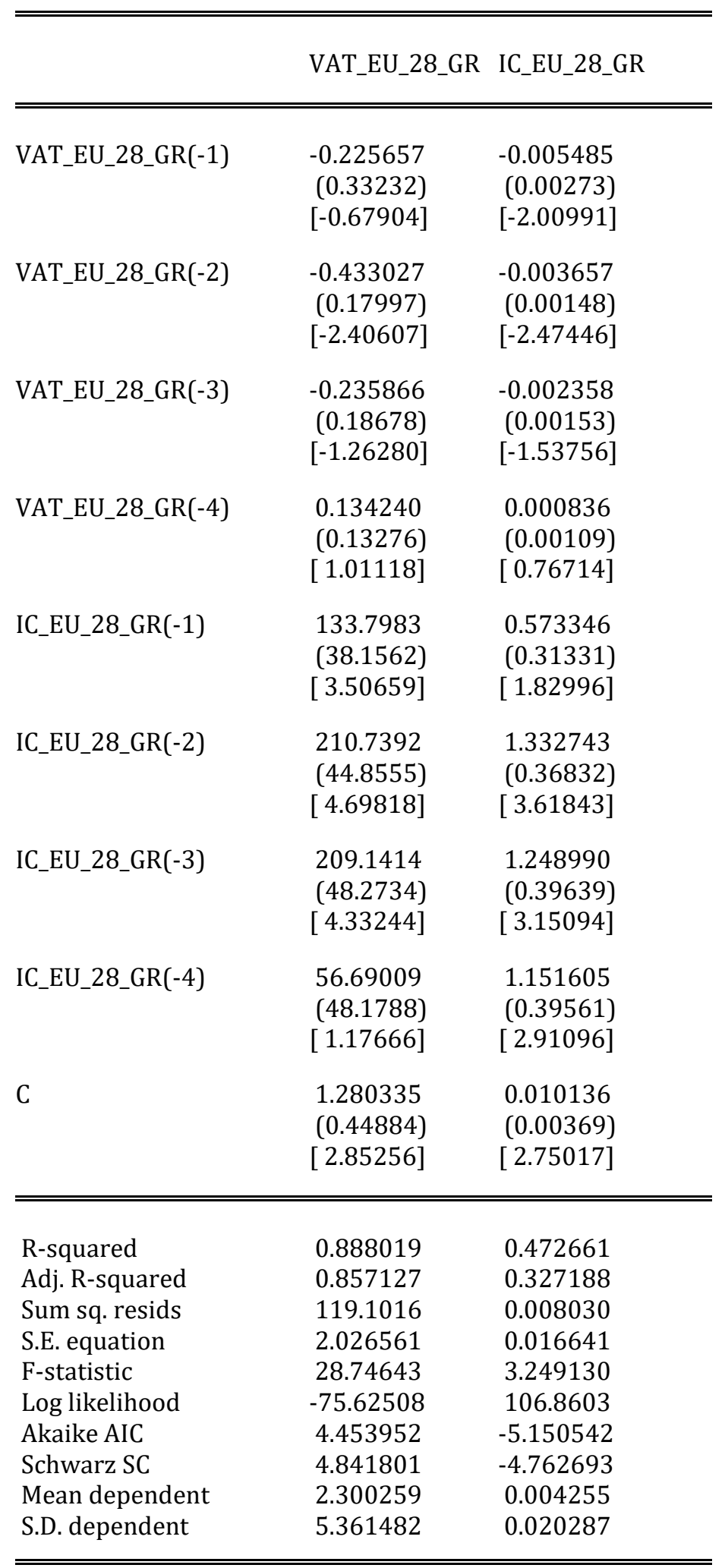

Standard errors in ( ) \& t-statistics in []

Source: Authors' own research 
Before analyzing impulse-response functions, an assessment of residuals is required to see to what extent the models perform.

A first finding is that errors are autocorrelated, both in the model for Romania and in the model for EU-28. However, the correlograms reveal that a compromise can be made from this point of view (Figures 3 and 4). On the other hand, residuals are normally distributed in the case of Romania but do not have a normal distribution for EU-28 (Tables 12 and 13). Finally, the residuals are homoskedastic in the case of Romania, but they present heteroskedasticity in the case of the Union as a whole (Tables 14 and 15). Therefore, the interpretation of the results of these models should be done with caution.

Autocorrelations with 2 Std.Err. Bounds

Cor(VAT RO GR,VAT RO GR(-i))

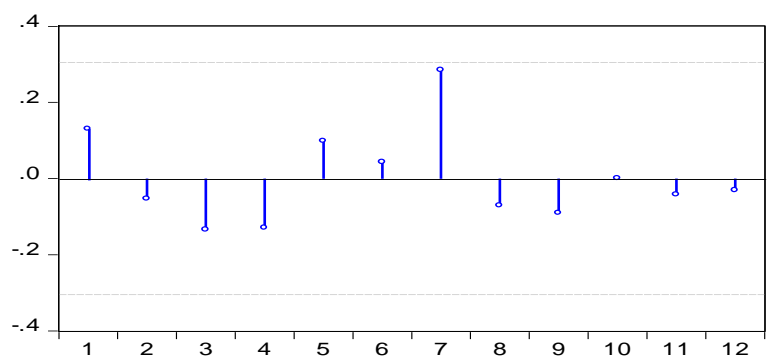

Cor(IC_RO_GR,VAT_RO_GR(-i))

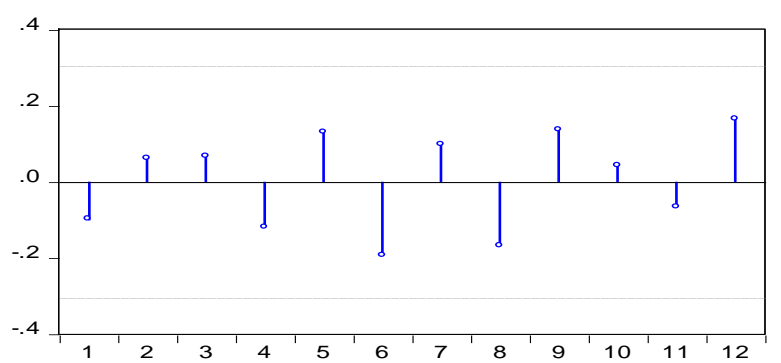

Cor(VAT RO GR,IC RO GR(-i))

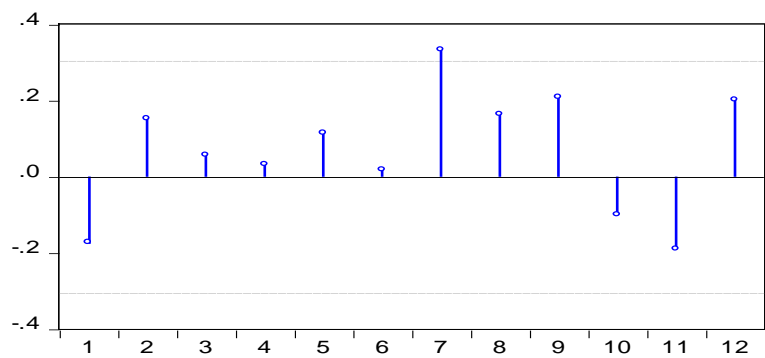

Cor(IC_RO_GR,IC_RO_GR(-i))

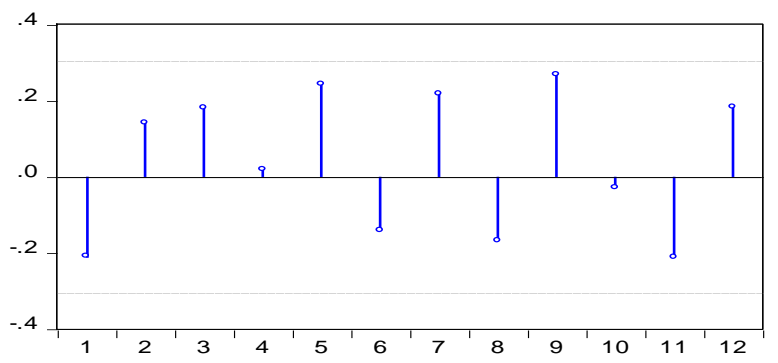

VAR Residual Portmanteau Tests for Autocorrelations

Null Hypothesis: no residual autocorrelations up to lag h

Sample: 2007Q1 2018Q3

Included observations: 43

\begin{tabular}{cccccc}
\hline \hline Lags & Q-Stat & Prob. & Adj Q-Stat & Prob. & df \\
\hline \hline 1 & 6.101074 & $\mathrm{NA}^{*}$ & 6.246338 & $\mathrm{NA}^{*}$ & $\mathrm{NA}^{*}$ \\
2 & 8.757253 & $\mathrm{NA}^{*}$ & 9.032087 & $\mathrm{NA}^{*}$ & $\mathrm{NA}^{*}$ \\
3 & 12.24823 & $\mathrm{NA}^{*}$ & 12.78489 & $\mathrm{NA}^{*}$ & $\mathrm{NA}^{*}$ \\
4 & 13.82541 & $\mathrm{NA}^{*}$ & 14.52383 & $\mathrm{NA}^{*}$ & $\mathrm{NA}^{*}$ \\
5 & 16.51015 & 0.0024 & 17.56182 & 0.0015 & 4 \\
\hline \hline
\end{tabular}

*The test is valid only for lags larger than the VAR lag order.

$\mathrm{df}$ is degrees of freedom for (approximate) chi-square distribution

Figure 3 - The results of autocorrelations tests for Romania

Source: Authors' own research 
Autocorrelations with 2 Std.Err. Bounds

Cor(VAT_EU_28_GR,VAT_EU_28_GR(-i))

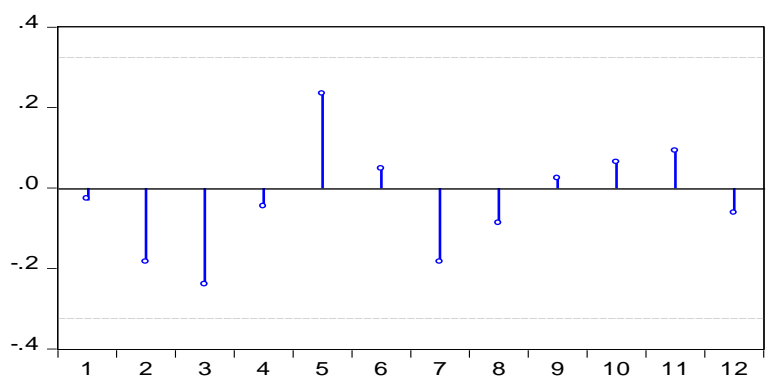

Cor(IC_EU_28_GR,VAT_EU_28_GR(-i))

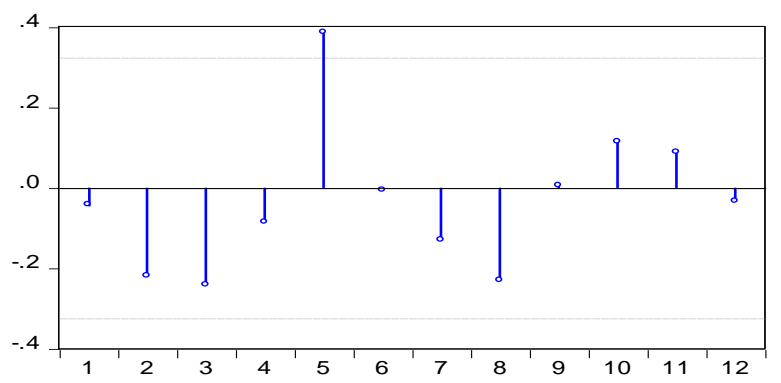

Cor(VAT_EU_28_GR,IC_EU_28_GR(-i))

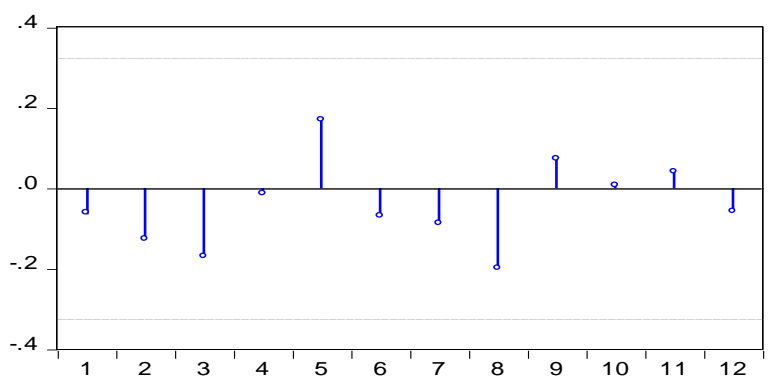

Cor(IC_EU_28_GR,IC_EU_28_GR(-i))

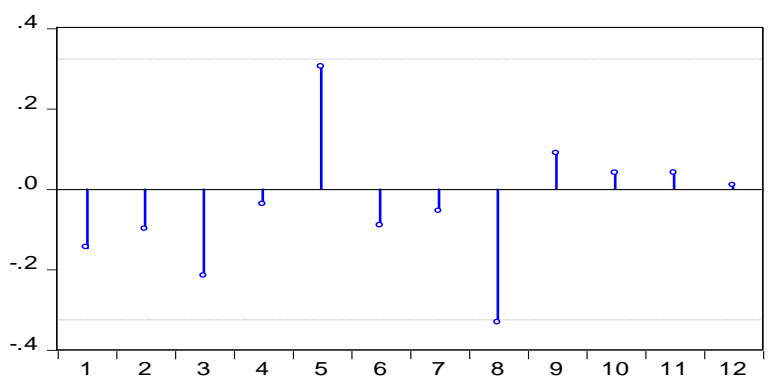

VAR Residual Portmanteau Tests for Autocorrelations

Null Hypothesis: no residual autocorrelations up to lag $\mathrm{h}$

Sample: 2007Q1 2018Q3

Included observations: 38

\begin{tabular}{cccccc}
\hline \hline Lags & Q-Stat & Prob. & Adj Q-Stat & Prob. & df \\
\hline \hline 1 & 4.808574 & $\mathrm{NA}^{*}$ & 4.938536 & $\mathrm{NA}^{*}$ & $\mathrm{NA}^{*}$ \\
2 & 9.807817 & $\mathrm{NA}^{*}$ & 10.21551 & $\mathrm{NA}^{*}$ & $\mathrm{NA}^{*}$ \\
3 & 13.75316 & $\mathrm{NA}^{*}$ & 14.49903 & $\mathrm{NA}^{*}$ & $\mathrm{NA}^{*}$ \\
4 & 14.45403 & $\mathrm{NA}^{*}$ & 15.28235 & $\mathrm{NA}^{*}$ & $\mathrm{NA}^{*}$ \\
5 & 22.38811 & 0.0002 & 24.41856 & 0.0001 & 4 \\
\hline \hline
\end{tabular}

*The test is valid only for lags larger than the VAR lag order.

$\mathrm{df}$ is degrees of freedom for (approximate) chi-square distribution

\section{Figure 4 - The results of autocorrelations tests for EU-28}

Source: Authors' own research

Table 12 - The results of residual normality tests for Romania

VAR Residual Normality Tests

Orthogonalization: Cholesky (Lutkepohl)

Null Hypothesis: residuals are multivariate normal

Sample: 2007Q1 2018Q3

Included observations: 43

\begin{tabular}{ccccc}
\hline \hline Component & Skewness & Chi-sq & df & Prob. \\
\hline \hline 1 & -0.082293 & 0.048534 & 1 & 0.8256 \\
2 & 0.473929 & 1.609697 & 1 & 0.2045 \\
\hline \hline Joint & & 1.658231 & 2 & 0.4364
\end{tabular}




\begin{tabular}{ccccc}
\hline \hline Component & Kurtosis & Chi-sq & df & Prob. \\
\hline \hline 1 & 2.380327 & 0.687991 & 1 & 0.4068 \\
2 & 3.222416 & 0.088632 & 1 & 0.7659 \\
\hline \hline Joint & & 0.776624 & 2 & 0.6782 \\
\hline \hline
\end{tabular}

\begin{tabular}{cccc}
\hline \hline Component & Jarque-Bera & df & Prob. \\
\hline \hline 1 & 0.736525 & 2 & 0.6919 \\
2 & 1.698329 & 2 & 0.4278 \\
\hline \hline Joint & 2.434854 & 4 & 0.6563 \\
\hline \hline
\end{tabular}

Source: Authors' own research

Table 13 - The results of residual normality tests for EU-28

VAR Residual Normality Tests

Orthogonalization: Cholesky (Lutkepohl)

Null Hypothesis: residuals are multivariate normal

Date: 05/15/19 Time: 17:33

Sample: 2007Q1 2018Q3

Included observations: 38

\begin{tabular}{|c|c|c|c|c|}
\hline Component & Skewness & Chi-sq & df & Prob. \\
\hline 1 & -1.716904 & 18.66915 & 1 & 0.0000 \\
\hline 2 & -0.171977 & 0.187315 & 1 & 0.6652 \\
\hline Joint & & 18.85646 & 2 & 0.0001 \\
\hline Component & Kurtosis & Chi-sq & df & Prob. \\
\hline 1 & 8.173129 & 42.37200 & 1 & 0.0000 \\
\hline 2 & 3.155909 & 0.038487 & 1 & 0.8445 \\
\hline Joint & & 42.41049 & 2 & 0.0000 \\
\hline Component & Jarque-Bera & df & Prob. & \\
\hline 1 & 61.04115 & 2 & 0.0000 & \\
\hline 2 & 0.225803 & 2 & 0.8932 & \\
\hline Joint & 61.26695 & 4 & 0.0000 & \\
\hline
\end{tabular}


Table 14 - The results of White test for Romania

VAR Residual Heteroskedasticity Tests: No Cross Terms (only levels and squares)

Sample: 2007Q1 2018Q3

Included observations: 43

Joint test:

\begin{tabular}{ccc}
\hline \hline Chi-sq & df & Prob. \\
\hline \hline 79.36766 & 48 & 0.0029 \\
\hline \hline
\end{tabular}

Individual components:

\begin{tabular}{lccccc}
\hline \hline Dependent & R-squared & F(16,26) & Prob. & Chi-sq(16) & Prob. \\
\hline \hline res1*res1 & 0.562272 & 2.087351 & 0.0461 & 24.17769 & 0.0857 \\
res2*res2 & 0.758235 & 5.096412 & 0.0001 & 32.60412 & 0.0083 \\
res2*res1 & 0.570176 & 2.155618 & 0.0395 & 24.51757 & 0.0788 \\
\hline \hline
\end{tabular}

Source: Authors' own research

Table 15 - The results of White test for EU-28

VAR Residual Heteroskedasticity Tests: No Cross Terms (only levels and squares)

Date: 05/15/19 Time: 17:34

Sample: 2007Q1 2018Q3

Included observations: 38

\begin{tabular}{|c|c|c|c|c|c|}
\hline \multicolumn{3}{|l|}{ Joint test: } & & & \\
\hline Chi-sq & df & Prob. & & & \\
\hline 57.07439 & 48 & 0.1735 & & & \\
\hline \multicolumn{6}{|c|}{ Individual components: } \\
\hline Dependent & R-squared & $F(16,21)$ & Prob. & Chi-sq(16) & Prob. \\
\hline res1*res1 & 0.786730 & 4.841678 & 0.0005 & 29.89575 & 0.0186 \\
\hline res2*res2 & 0.817713 & 5.887689 & 0.0001 & 31.07310 & 0.0132 \\
\hline res2*res1 & 0.805423 & 5.432915 & 0.0002 & 30.60609 & 0.0151 \\
\hline
\end{tabular}

Source: Authors' own research

The analysis of impulse-response functions leads to the following estimations:

- A positive impulse in intermediate consumption (e.g. increasing the growth rate by one percentage point) leads to a slight increase of VAT revenue in long-term, for Romania; instead, a positive impulse in VAT revenue growth leads to a sharp drop in intermediate consumption in the first two years (short-term), to a relative increase over the next 7 years and to a further decline over the last period (Figure 5).

- At the EU-28 level, a positive impulse in intermediate consumption leads to a steep 
rise in VAT revenues in the long term; instead, a positive impuls in raising VAT revenue leads to a long-term compression in intermediate consumption (Figure 6).

Although the results have to be viewed with reserve, the more so as the bands of variation include the zero value, the identified relations correspond to the economic logic and confirm the central hypothesis, with several mentions for Romania, given the atypical evolutions of the variables in this space.

The results indicate that an increase of the tax revenues based on the increase of the taxation will lead to a compression of the economic activity on the short term, the return to the initial level taking place in a longer term. The alternative is to increase tax revenue by stimulating the economic activity based on coherent economic policies. On the other hand, the pattern of variation of the variables shows that in Romania the hidden economy is significant. This requires from the authorities consistent measures to control a large part of the shadow economy. The high share of undeclared economic activity explains Romania's poor performance in VAT collection compared to other EU Member States.
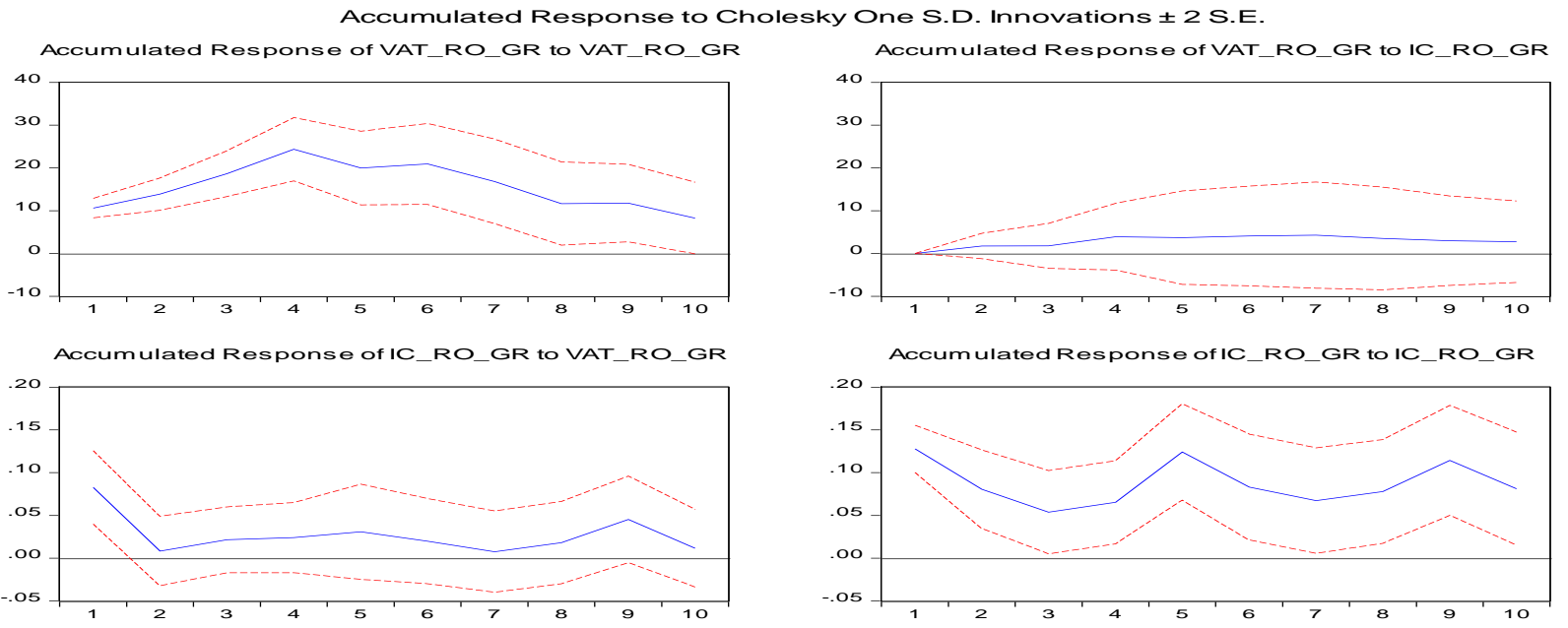

Figure 5 - The impulse-response functions for Romania Source: Authors' own research

Accumulated Response to Cholesky One S.D. Innovations \pm 2 S.E. Accumulated Response of VAT_EU_28_GR to VAT_EU_28_GR

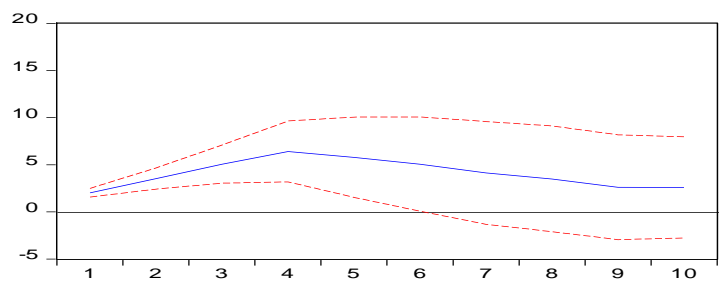

Accumulated Response ofVAT_EU_28_GR to IC_EU_28_GR
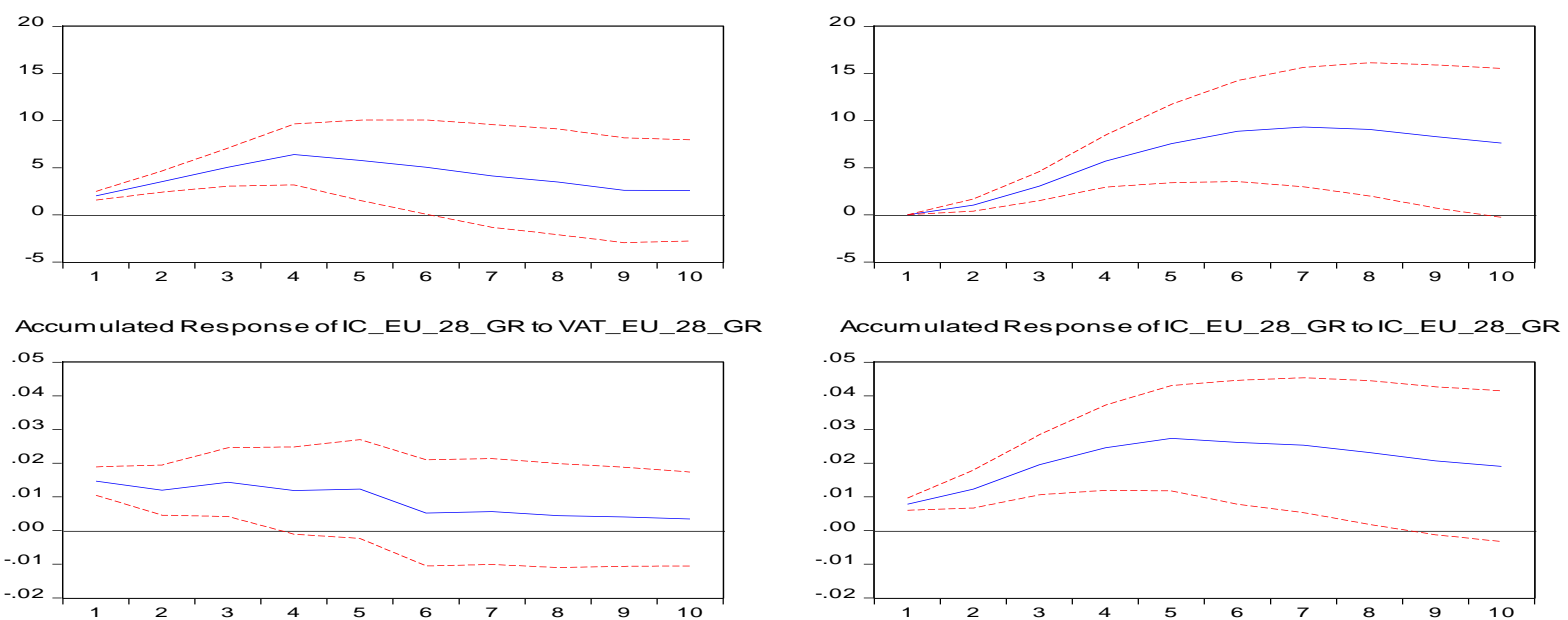

Figure 6 - The impulse-response functions for EU-28

Source: Authors' own research 


\section{Conclusion}

Overall, the central hypothesis has been confirmed, but the results reveal atypical situations, worth mentioning. In Romania, there is a high volatility in the volume of transactions between economic agents, reflecting some economic instability or the significant influence of the hidden economy. Moreover, there is no direct link between VAT tax revenue in Romania and an important component of the related tax base, surprisingly; tax revenue tend to have a relatively constant growth rate regardless of the sense and magnitude of the change in volume of the base of taxation. A positive impulse in intermediate consumption, thus increasing economic relations between market players, leads to a slight increase in tax revenues in Romania compared to the Union as a whole, where a positive impulse in intermediate consumption significantly increases tax revenue in VAT.

Thus, intermediate consumption can be considered as a predictor of VAT revenue and can be entered as a variable in a forecasting model. In the case of Romania, however, research needs to be expanded to identify the causes that led to atypical variations. The results of this study are also useful for assessing the impact of a possible implementation of the generalized reverse charge mechanism, intermediate consumption being exempt from VAT in such a mechanism.

The results indicate that the most likely sense of the causality is from intermediate consumption to VAT revenue, the regression equations related to this link explaining $70 \%$ of growth rate of VAT revenue variation, in the case of Romania, and 85\%, in the case of the Union as a whole. Specifically, the variation of current VAT revenue is explained by the aggregate impact of the previous year's VAT revenue as well as the current intermediate consumption and the previous year's intermediate consumption. The data show that Romania did not enter into a post-accession convergence process (1 January 2007). In the EU-28, the intermediate consumption growth rate is relatively constant, while intermediate consumption in Romania is highly volatile. Also, the VAT revenue growth rate is relatively volatile in Romania compared to EU-28, but tends to stabilize, which is hard to explain in the context of a high volatility in the tax base.

Given that there is no direct link between intermediate consumption and VAT revenues, in the case of Romania, a specific model of estimating and forecasting VAT revenue should be developed. On the other hand, the results of our study show that the variation of intermediate consumption is very volatile, which would reveal an influence of the hidden economy.

\section{Limits of the study and further research}

The results should be viewed with caution because not all variables were stationary in the level, but mostly because the residuals are autocorrelated, are not distributed normally in all cases, and show heteroskedasticity in some variables. A larger number of observations would increase the performance of the regression models, but a longer series of data would not have been relevant from the perspective of this study: it was interested in the evolution of the variables considered especially after Romania's accession to the European Union. For this reason, we worked with only 47 observations (quarterly data for the period 2007-2018) wich limits the analysis. 
Given the findings of this study and its limits it is needed for further research in order to design proper models of forcasting and estimation in the case of Romania. Moreover, research needs to be expanded to identify the causes that led to atypical variations.

\section{References}

Afonso A. \& Sousa R. (2011). The Macroeconomic Effects of Fiscal Policy in Portugal: a Bayesian SVAR Analysis. Portuguese Economic Journal, vol. 10(1), April.

Al-Abbadi, H. \& Abdel Khaliq, S. (2017). The Causal Relationship between Sales Tax Revenue and Economic Growth in Jordan. International Research Journal of Applied Finance, VIII, 170.

Barro, R. \& Sala-i-Martin, X.I. (1995). Economic Growth (2nd ed.). New York: McGraw Hill.

Bird, R.M. \& Gendron, P-P. (2006). Is VAT the best way to impose a general consumption tax in developing countries?. International Studies Program, working paper 06-17, 2006, Georgia State University.

Bogetic, Z. \& Hassan, F. (1993). Determinants of Value-Added Tax Revenue. A Cross-Section Analysis. The World Bank, working paper 1203, Europe and Central Asia Country Department.

Boiciuc, I. (2015). The effects of fiscal policy shocks in Romania. A SVAR Approach. Procedia Economics and Finance, 32 (2015) 1131-1139, Elsevier.

Brașoveanu, L.O. \& Brașovanu, I. (2008). The Correlation between Fiscal Policy and Economic Growth. Theoretical and Applied Economics, 7(7), 19-26.

de Castro Fernández F. \& Hernández de Cos P. (2006). The economic effects of exogenous fiscal shocks in Spain. A SVAR Approach. European Central Bank, Working paper series, online at http://www.ecb.europa.eu/pub/pdf/scpwps/ecbwp647.pdf.

Enache, C. (2009). Fiscal policy and economic growth in Romania. Annales Universitatis Apulensis Series Oeconomica, 11(1), 502-512.

European Commision (2015). Tax reforms in EU Member States. Tax policy challenges for economic growth and fiscal sustainability. Taxation paper no 58.

Feldstein, M \& Krugman, P (1989). Internal Effects of Value Added Taxation. Retrieved from www.nber.org/papers/w3163 on 5th March, 2019.

Giordano, R., Momigliano, S., Neri, S. \& Perotti, R. (2007). The effects of fiscal policy in Italy: Evidence from a VAR model. European Journal of Political Economy, 23, 707-733.

Harvey, A., (1990). The econometric Analysis of Time Series (2nd ed.). Cambridge: The MIT Press.

Kalaš, B., Mirović, V. \& Milenkovic, N. (2018). The relationship between taxes and economic growth: Evidence from Serbia and Croatia. The European Journal of Applied Economics, 15.17-28.10.5937/EJAE15-18056, 17-28.

Kawano, L. \& Slemrod, J. (2012). The Effect of Tax Rates and Tax Bases on Corporate Tax Revenues: Estimates with New Measures of the Corporate Tax Base. National Bureau of Economic Research 1050, Working Paper 18440, Massachusetts Avenue Cambridge, MA, retrieved from www.nber.org/papers/w3163 on 6th March, 2019.

Kuismanen M. \& Kämppi V. (2010). The effects of fiscal policy on economic activity in Finland. Economic Modelling, 27(5), September 2010, 1315-1323.

Leibfritz, W., Thornton J. \& Bibbee A. (1997). Taxation and Economic Performance. OECD Economics Department Working Papers, No. 176, OECD Publishing.

Mureșan, M., David, D., Elek, L. \& Dumiter, F. (2014). Value Added Tax Impact On Economic Activity: Importance, Implication And Assessment - The Romanian Experience. Transylvanian Review of Administrative Sciences, Special Issue/2014, 131-151.

Mamatzakis E. C. (2005). The dynamic responses of growth to tax structure for Greece. Applied Economics Letters, Taylor \& Francis Journals, 12(3), 177-180.

Mutaşcu, M.I. \& Dănuleţiu, D.C. (2011). Taxes And Economic Growth In Romania. A Var Approach. Annales Universitatis Apulensis Series Oeconomica, 13(1), 94-105. 
Okoli, M.N. \& Afolayan, S.M., (2015). Correlation between Value Added Tax (VAT) and National Revenue in Nigeria: An ECM model. Research Journal of Finance and Accounting, www.iiste.org, ISSN 2222-1697 (Paper), ISSN 2222-2847 (Online), 6(6), 2015.

Perotti, R. (2004). Estimating the effects of fiscal policy in OECD countries. University of Bocconi, Working Paper.

Romer C.D. \& Romer D.H. (2010). The Macroeconomic Effects of Tax Changes: Estimates Based on a New Measure of Fiscal Shocks. American Economic Review, American Economic Association, 100(3), June 2010, 763-801.

Tanzi, V. \& Zee, H.H. (2000). Tax Policy for Emerging Markets: Developing Countries. National Tax Journal, 53(3), June 2000, 299-322. Retrieved from https:// www.researchgate.net/publication/240272972_Tax_Policy_for_Emerging_MarketsD eveloping_ Countries 